\title{
Virtual Water Flows at the County Level in the Heihe River Basin, China
}

\author{
Yali Zhang ${ }^{1,2}$, Qing Zhou ${ }^{1,2,3}$ and Feng $W^{1,2, *}$ \\ 1 Institute of Geographic Sciences and Natural Resources Research, Chinese Academy of Sciences, \\ Beijing 100101, China; zhangyali@igsnrr.ac.cn (Y.Z.); zhouq.14b@igsnrr.ac.cn (Q.Z.) \\ 2 Center for Chinese Agricultural Policy, Chinese Academy of Sciences, Beijing 100101, China \\ 3 University of Chinese Academy of Sciences, Beijing 100049, China \\ * Correspondence: wufeng@igsnrr.ac.cn; Tel.: +86-106-488-9837
}

Received: 29 June 2017; Accepted: 5 September 2017; Published: 14 September 2017

\begin{abstract}
Water scarcity in arid regions can be addressed by using the virtual water concept in water resources management. This research used a compiled county-level input-output table to analyze virtual water flows for the Heihe River Basin in 2012 by applying a multi-regional input-output (MRIO) model. The results showed that the Heihe River Basin is a net virtual water exporter at a scale of 1.05 billion $\mathrm{m}^{3}$, which accounts for one third of the total amount of the basin's water resources. The midstream area of the basin imports $96.31 \%$ of virtual water $\left(2.04\right.$ billion $\mathrm{m}^{3}$ ) and exports $88.84 \%$ of virtual water $\left(0.94\right.$ billion $\left.\mathrm{m}^{3}\right)$. In contrast, the upstream and downstream parts have limited virtual water flows. The agricultural sector largely consumes water in each county; maize or wheat production accounts for approximately $50 \%$ of the total water consumption. For most sectors, the virtual water content from surface water is greater than that from groundwater. The ratio of virtual surface water to virtual groundwater ranges from 1.20 to 2.91 . The results for the water stress index indicated that most counties experienced water stress due to maize production. Greater attention needs to be paid to the adaptation and assessment of virtual water strategies in arid regions.
\end{abstract}

Keywords: virtual water; multi-regional input-output model; water stress index; Heihe River Basin

\section{Introduction}

Arid land covers approximately $41 \%$ of the world's land surface. Water scarcity in arid and semi-arid regions has been severe [1]. In water-scarce regions, water resource sustainability, ecosystem health, and socio-economic development are dependent on water, which is the central determining factor [2]. To address water shortage issues, management interventions have been made. These interventions include water diversion projects (such as China's South-North Water Transfer), implementing the use of water-saving technology, industrial structure adjustments, and using virtual water strategies. Virtual water was defined by Allan (1997) as "the water embedded in internationally traded goods" based on economic theory [3]. According to virtual water principles, water-scarce regions with spatial mismatches in water and arable land availability can improve their food security by purchasing a portion of their food requirements through agricultural trade (thus acquiring virtual water) and cutting local food production (thus using less local water). A flourishing literature has been inspired on dealing with water scarcity through virtual water trade, whereas it is still under debate [4-6].

To mitigate water stress, some researchers believe that food trade to increase virtual water in water-scarce regions is an efficient use of water resources [7,8]. Different crop trades save or lose different volumes of blue and green water. Nevertheless, others have argued that the virtual water trade strategy as a solution to water scarcity is fallacious [6,9]. In practice, producing grain in some arid regions has a competitive advantage over humid regions. Furthermore, virtual water flows have 
varied effects on water stress for the water-receiving regions and the water-exporting regions. The key to mitigate water stress is improving water use efficiency, whereas the efficiency benefits will be highly compensated by the increased water demand caused by developed economy.

Social equity and adaptability can in theory result in the allocation of virtual water. Virtual water use is highly unequal, and is almost completely explained by social development status rather than water scarcity [10]. Urbanization leads to a change in the requirements from industry, which in turn leads to changes in urbanization rates and urban poverty rates. In addition, if a country (or region) is scarce in water resources but rich in socio-economic resources, its social adaptability would lead to an industrial structure with relatively richer virtual water resources [11]. Agricultural water use dominates national water demands and cannot be completely compensated for virtual water transfers. Virtual water strategies can increase social transactions, which should give priority to guaranteeing people's purchasing power. The theory of comparative advantage in implementing virtual water strategy could be used to learn the economic attractiveness of virtual water import and export [12]. Moreover, the virtual water strategy implementation will reduce the pressure of ecological water shortage and thereby change the regional food production mode [1,13]. In general, the agriculture sector largely consumed water resources with low water productivity, and the only feasible approach is to save water resources by improving the water use efficiency. On the other hand, agricultural water use can be saved by introducing the virtual water strategy and reasonably decreasing the agricultural land area, thus indirectly increasing the ecological water use. Seeking a balance between agricultural production and ecological conservation is of important value to guiding the ecological sustainability in the ecologically fragile water-scarce regions [13]. Virtual water concept brings global insights across countries for improving water and land management, fostering adaptation strategies to transboundary resource management.

Previous studies focused primarily on national-level and provincial-level virtual water issues. Only a few studies have addressed virtual water flows at the county level, and have addressed the feasibility of inter-basin virtual water strategies $[6,8]$. Thus, the aims of this paper are to address this knowledge gap by: (1) assessing the virtual water flows at the county level, river basin level and sector level for the Heihe River Basin; (2) distinguishing between surface water and groundwater flows in virtual water import and export; and (3) evaluating the water stress status of the Heihe River Basin. This study will provide policy implications for water resources management from the perspective of virtual water and industrial structures in arid regions.

\section{Study Area and Data}

\subsection{Study Area}

The Heihe River Basin, located in the arid regions of Northwest China, is the second largest inland river basin in China with an area of $116,000 \mathrm{~km}^{2}$ and a mean runoff of $2800 \mathrm{Mm}^{3} / \mathrm{a}$. The main stream of the Heihe River originates from the Qilian Mountain, which is mainly located in Qinghai Province. The river flows through the Hexi corridor of the Gansu Province and terminates in the Juyanhai Lake on the Inner Mongolia Plateau (Figure 1). The Heihe River Basin has been divided into upstream, midstream and downstream areas by the boundary lines of two hydrological stations (Yingluoxia and Zhengyixia). The historical mean annual precipitation declines sharply from approximately $338 \mathrm{~mm}$ in the upstream area to $127 \mathrm{~mm}$ in the midstream area, and $49 \mathrm{~mm}$ in the downstream area (China Meteorological Administration).

There are relatively abundant water resources in the upstream areas compared to the other two areas, especially the downstream area. Hills dominate the terrain in the upstream area, where animal husbandry is the main income source for farmers. The midstream area consists of broad, flat plains that are suitable for irrigated agriculture, which accounts for the majority of the water consumption in the basin. In contrast, the downstream area is mainly desert. Discharge in the downstream area has decreased significantly, and more than 30 tributaries, as well as the terminal lakes, have dried 
up. The Heihe River Basin is an exemplary region in China experiencing water scarcity. Rapid population growth, economic expansion, abrupt water exploitation, and irrational water allocation have accelerated ecological degradation over the last five decades [14].

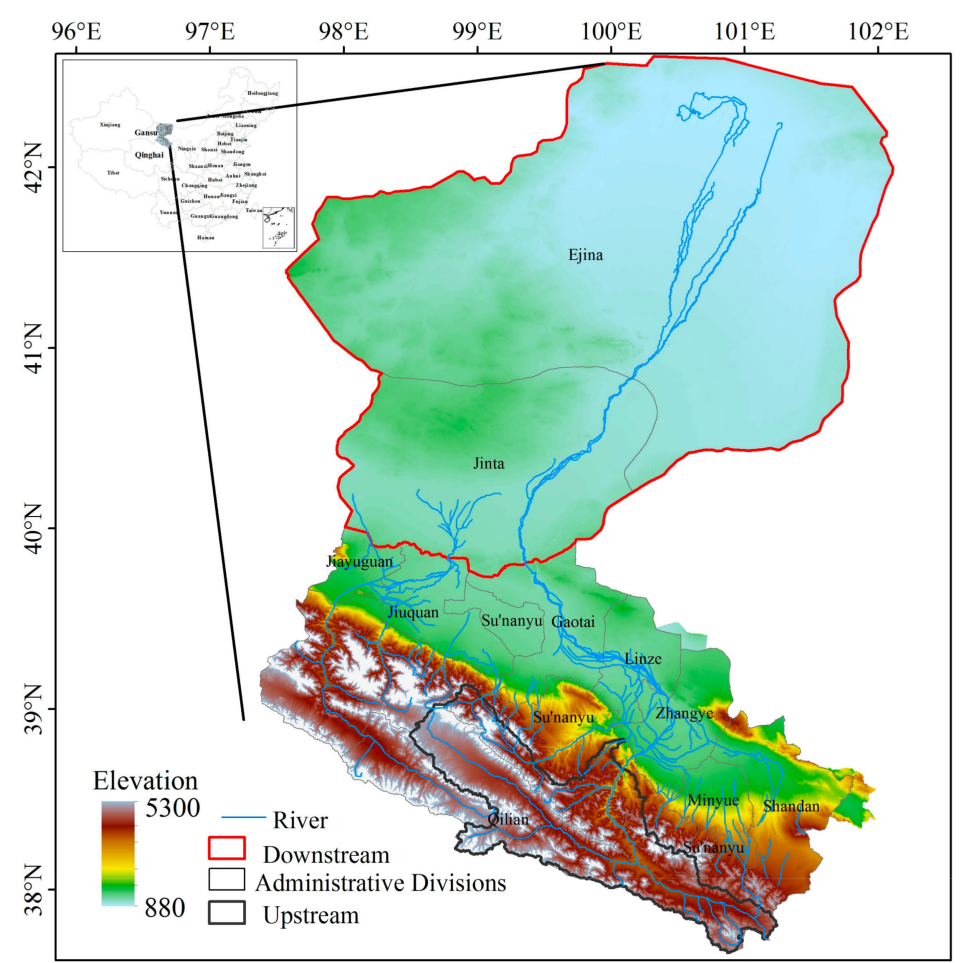

Figure 1. Map of the study area.

\subsection{Methods}

\subsubsection{Multi-Regional Input-Output Model}

The multi-regional input-output (MRIO) model is a useful tool for capturing the economic relationships among different regions and sectors, and is based on the input-output (IO) table method formulated by Leontief. The MRIO model has the ability to trace the spatial transfers of ecological and environmental damage, and has been widely used to investigate virtual water footprints [15-17]. This study applies the MRIO model at the county level for the Heihe River Basin. In the MRIO table, the Heihe River Basin consists of 11 counties, and the sectors have been aggregated into 48 sectors. In the basic IO model, economic output can be expressed as the sum of intermediate consumption and final demand. The Leontief IO relationship is as follows:

$$
x=(I-C)^{-1} y
$$

where $x$ is the vector of economic output, $I$ represents the identity matrix, $C$ is the direct IO coefficients matrix, and $y$ is the vector of the final demand. The water resource is divided into groundwater and surface water in the IO table. 
In this study, a MRIO model was employed to extend the standard IO matrix to a larger economy in which each sector in each county is assigned a separate row and column. Equation (1) can thus be generalized to include imports from other counties, as formulated in Equation (2):

$$
\left(\begin{array}{c}
x_{1} \\
x_{2} \\
\vdots \\
x_{n}
\end{array}\right)=\left(\begin{array}{cccc}
C_{11} & C_{12} & \cdots & C_{11} \\
C_{21} & C_{22} & \cdots & C_{21} \\
\vdots & \vdots & \ddots & \vdots \\
C_{n 1} & C_{n 2} & \cdots & C_{n 1}
\end{array}\right)\left(\begin{array}{c}
x_{1} \\
x_{2} \\
\vdots \\
x_{n}
\end{array}\right)+\left(\begin{array}{c}
\sum_{\mathrm{s}} y_{1 j} \\
\sum_{\mathrm{s}} y_{2 j} \\
\vdots \\
\sum_{\mathrm{s}} y_{n j}
\end{array}\right)
$$

where $x_{j}$ indicates the total output of production and consumption in region $j, y_{i j}$ indicates each sector's output produced in region $i$ and consumed in region $j$, and $C_{i j}$ reflects the intermediate consumption; each column denotes the input from each sector in region $i$ required to produce one unit of output from each sector in region $j$.

Virtual water flows $(V W)$ are calculated as:

$$
V W=k_{\mathcal{c}}(I-C)^{-1} y
$$

where $k_{c}$ is a row vector of water consumption per unit of sectorial output.

\subsubsection{Water Stress Index}

Water stress is defined as the ratio of total annual freshwater withdrawals to total freshwater availability. This paper adopts the water stress index (WSI) as defined by Pfister et al. (2009) and adjusts it for virtual water [18]. The WSI is expressed as:

$$
W S I=\frac{W C+V W_{e x}-V W_{i m}}{Q}
$$

where $W C$ refers to water consumption. $V W_{i m}$ is virtual water import, and $V W_{e x}$ is virtual water export. $Q$ is renewable freshwater availability. Water stress is defined as moderate and extreme above a threshold of 0.4 and 0.8 , respectively.

\subsection{Data Sources}

The IO table at the county level of the Heihe River Basin was compiled and cited from the research project "the National Natural Science Foundation of China (Grant No. 91325302)". The IO table on water consumption at the sector level for 11 counties was obtained by the combination of survey methods and non-survey methods. The IO technical coefficients of key sectors at the county level were determined by survey methods, while those of other sectors were adopted by provincial-level coefficients. Total output values of sectors were derived from the Statistics Yearbook in 2012. The volumes of surface water and groundwater were collected from the Bulletin of first national census for water, which was conducted by the Ministry of Water Resources.

\section{Results and Discussion}

\subsection{Virtual Water Import and Export at the County Level}

The agricultural sector consumed the largest amount of water in each county in the Heihe River Basin (Table 1). The water consumption of the secondary and tertiary industries was less than that of agricultural production. Water consumption structures at the county level in 2012 showed that regions with grain production had high levels of water consumption; corn or wheat production accounted for the largest proportion (almost 50\%) of total water consumption. For example, the water use for corn production in Ganzhou County accounted for $54.53 \%\left(449.07\right.$ million $\left.^{3}\right)$ of total water consumption, while the proportion of consumption for wheat was $44.58 \%\left(66.64\right.$ million $\left.\mathrm{m}^{3}\right)$ in 
Shandan County. The water consumption results can be captured in consumption coefficients for each sector. The coefficients in the agricultural sector of Zhangye city (including Ganzhou, Sunan, Minle, Linze, Gaotai and Shandan Counties) was $0.15 \mathrm{~m}^{3}$ /yuan in 2012, which was $0.05 \mathrm{~m}^{3} /$ yuan higher than that of Jiayuguan County, and $0.02 \mathrm{~m}^{3} /$ yuan higher than that of the national level for China in 2002 [19].

Table 1. Water consumption for key sectors at county level of the Heihe River Basin $\left(10^{4} \mathrm{~m}^{3}\right)$.

\begin{tabular}{ccccc}
\hline Counties & Total Water Consumption & Agricultural Sector & Corn Production & Wheat Production \\
\hline Qilian & 1694.21 & 1416.75 & 594.46 & 6.47 \\
Ganzhou & $82,351.67$ & $79,302.18$ & 5972.51 & $44,906.67$ \\
Sunan & $11,780.58$ & $11,434.79$ & 4248.49 & 5050.66 \\
Minle & $26,248.54$ & $25,456.54$ & 9865.74 & 1891.69 \\
Linze & $40,860.99$ & $40,027.45$ & 721.33 & $23,529.22$ \\
Gaotai & $42,757.56$ & $42,029.49$ & 5656.42 & $18,328.82$ \\
Shandan & $14,949.32$ & $13,731.75$ & 6664.54 & 419.14 \\
Suzhou & $19,267.03$ & $16,484.47$ & 3087.09 & 1572.70 \\
Jinta & $10,337.30$ & 2925.42 & 548.73 & 278.52 \\
Jiayuguan & $14,355.89$ & $13,655.25$ & 2556.02 & 1301.01 \\
Ejina & 1617.38 & 1010.80 & 114.83 & 376.62 \\
\hline
\end{tabular}

In this study, the MRIO model was applied to quantify the amount of imported and exported virtual water at the county level for the Heihe River Basin in 2012 (Figure 2). The total amount of virtual water imported into the Heihe River Basin was 1.06 billion $\mathrm{m}^{3}$, and the total amount of virtual water exported was 2.11 billion $\mathrm{m}^{3}$. Thus, the Heihe River Basin is a net virtual water exporter of 1.05 billion $\mathrm{m}^{3}$, accounting for $1 / 3$ of the total water resources in this region. Qilian, Ejina, and Jiayuguan Counties are the primary importing counties, while Ganzhou, Sunan, and the remaining counties are the virtual water exporting counties. Table 2 presents the details for the amounts of imported and exported virtual water at the county level for the Heihe River Basin. Ganzhou County stands out as the county which contributed significantly to both imported $\left(0.20\right.$ billion $\left.\mathrm{m}^{3}\right)$ and exported virtual water $\left(0.47\right.$ billion $\left.\mathrm{m}^{3}\right)$. The inter-county virtual water flows in the basin showed that the top three exporters of virtual water are Ganzhou, Linze and Gaotai Counties with amounts of $0.91,0.71$ and 0.66 million $\mathrm{m}^{3}$, respectively. The largest receiver of virtual water from other counties was Suzhou County $\left(1.13\right.$ million $\left.\mathrm{m}^{3}\right)$. Ganzhou County was the next biggest receiver of virtual water $\left(0.92\right.$ million $\left.\mathrm{m}^{3}\right)$ from counties within the basin. The key to mitigating severe water consumption in the Heihe River Basin is to adjust industry structures, and thus to optimize water consumption structures.

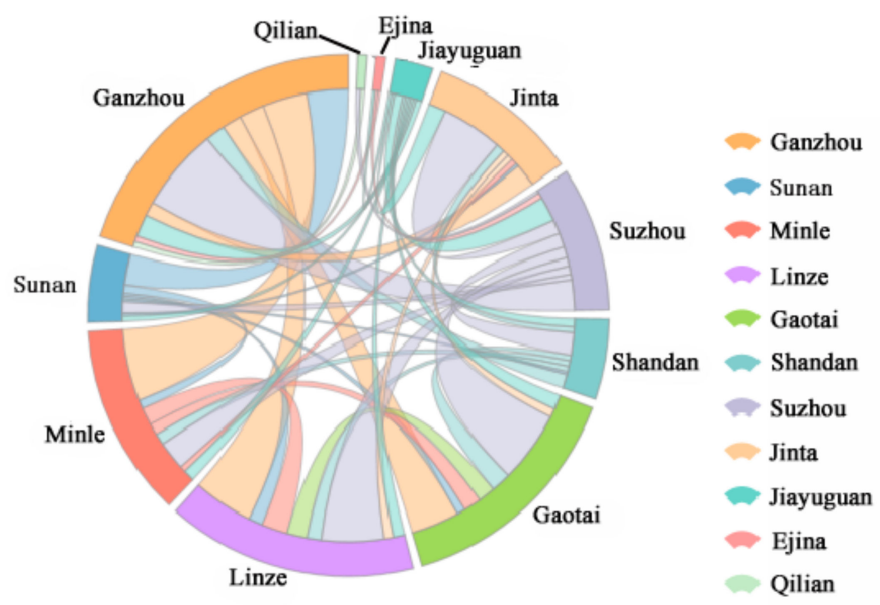

Figure 2. Virtual water imports and exports at the county level for the Heihe River Basin. The color of the links refers to the counties. 
Table 2. An account of the virtual water import and export at county level of the Heihe River Basin (unit: $10^{4} \mathrm{~m}^{3}$ ).

\begin{tabular}{cccccc}
\hline Counties & $\begin{array}{c}\text { Other Counties in } \\
\text { the Basin } \\
\text { (Exporters) }\end{array}$ & $\begin{array}{c}\text { Other Counties in } \\
\text { the Basin } \\
\text { (Receivers) }\end{array}$ & $\begin{array}{c}\text { Export } \\
\text { Outside the } \\
\text { Basin }\end{array}$ & $\begin{array}{c}\text { Import } \\
\text { Outside the } \\
\text { Basin }\end{array}$ & $\begin{array}{c}\text { Net Export } \\
\text { Outside the } \\
\text { Basin }\end{array}$ \\
\hline Qilian & 2.36 & 6.89 & 3043.54 & 5077.05 & -2033.51 \\
Ganzhou & 91.19 & 92.57 & $47,302.46$ & $20,123.45$ & $27,179.01$ \\
Sunan & 22.74 & 28.07 & 7096.40 & 5285.61 & 1810.79 \\
Minle & 54.77 & 37.96 & $17,769.94$ & 5735.70 & $12,034.24$ \\
Linze & 70.77 & 27.68 & $24,215.79$ & 4571.68 & $19,644.11$ \\
Gaotai & 66.12 & 26.08 & $25,678.01$ & 4614.42 & $21,063.59$ \\
Shandan & 21.87 & 30.24 & $10,309.50$ & 4558.34 & 5751.16 \\
Suzhou & 42.10 & 112.98 & $33,327.96$ & $21,301.00$ & $12,026.96$ \\
Jinta & 43.63 & 20.02 & $26,163.75$ & 7503.92 & $18,659.84$ \\
Jiayuguan & 9.73 & 37.93 & $11,665.25$ & $20,318.16$ & -8652.91 \\
Ejina & 0.65 & 8.49 & 4763.28 & 6727.54 & -1964.26 \\
\hline
\end{tabular}

Virtual water import implies increased water availability and might be one way to alleviate regional water stress. In contrast, the export of virtual water indicates increased water consumption, which contributes to water stress on local water resources [20,21]. A previous study on water consumption in the Hetao irrigation district showed that the export of virtual water contributed more pressure to water scarcity than local production [22]. The inter-basin virtual water flows (blue water) indicated that the total amount of virtual water imported into the Heihe River Basin was 4.29 million $\mathrm{m}^{3}$ and total virtual water exported from the basin was 4.26 million $\mathrm{m}^{3}$ (Table 2). This indicates that there was 0.03 billion $\mathrm{m}^{3}$ of virtual water imported specifically through inter-basin transfers. This reinforces our observation that inter-regional trade makes little contribution to alleviating water stress in water-scarce regions.

The Heihe River Basin was divided into three areas: upstream, midstream and downstream. Each area has distinct characteristics in terms of water resources, economic structure, household income and consumption patterns (Table 3). The upstream area (Qilian County) had small virtual water flows to and from the rest of the basin (Figure 3). In this area, the vegetation has been seriously degraded by deforestation, overgrazing, and grassland reclamation since the 1950s. The glacier area in the Heihe River Basin has decreased by $29.6 \%$ over the past 50 years [23]. The midstream area, which covers most areas of Ganzhou, Sunan, Minle, Linze, Gaotai, Shandan, Suzhou, Jinta and Jiayuguan Counties, exported $96.31 \%$ of virtual water $\left(2.04\right.$ billion $\mathrm{m}^{3}$ ) to outside the basin, and imported $88.84 \%$ of their virtual water $\left(0.94\right.$ billion $\left.\mathrm{m}^{3}\right)$ from outside the basin. Rapid agricultural development accounted for increased water consumption in the midstream area of runoff from the mountainous areas. In the Heihe River Basin, the agricultural land increase of 75 million $\mathrm{m}^{2}$ lead to the increasing water consumption of about 5 million $\mathrm{m}^{3}$. As a consequence of rapid agricultural development, both water use patterns and land use types underwent dramatic changes [14]. As with the upstream area, the downstream area (Ejina County) also had limited virtual water flows. The amount of physical water entering the downstream area decreased significantly from the 1950s to the 2000s as a result of the large expansion of irrigated farmlands in the midstream area. 


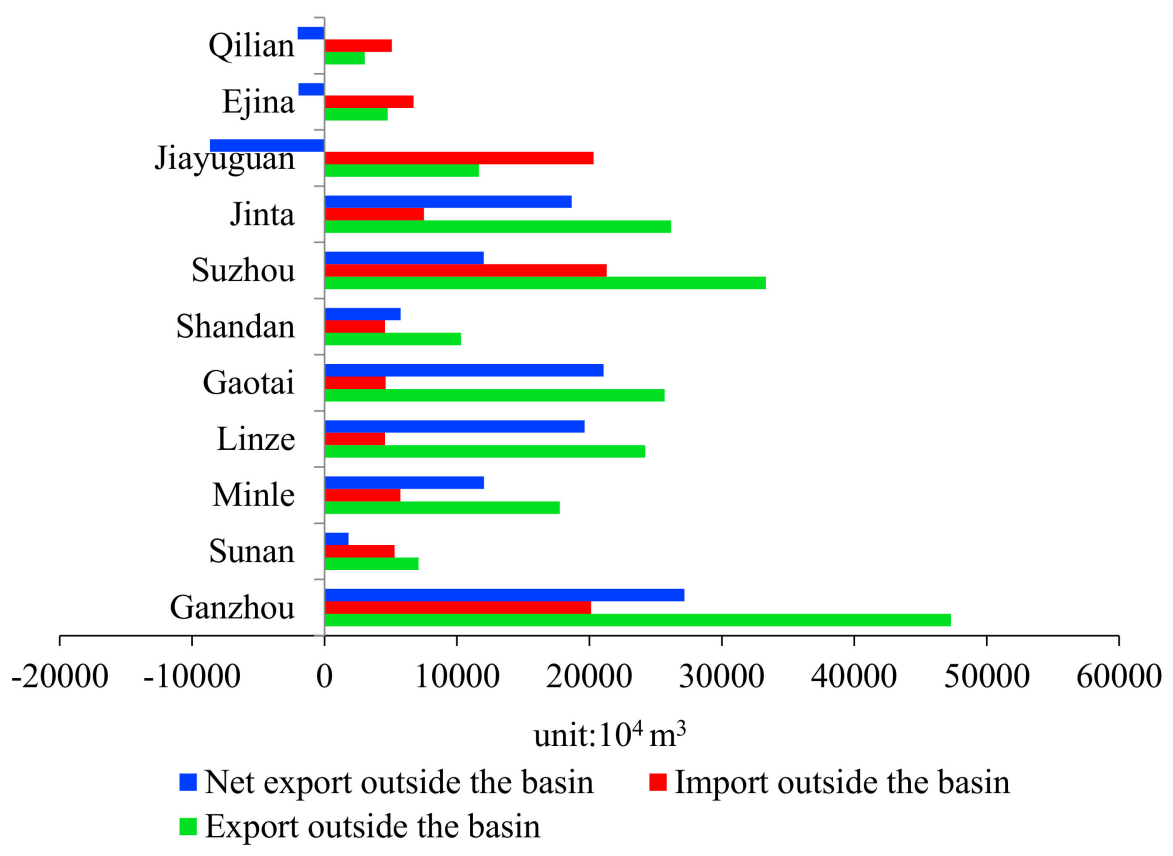

Figure 3. Virtual water flows between different counties in the Heihe River Basin.

Table 3. Socio-economic characteristics of the Heihe River Basin.

\begin{tabular}{ccccc}
\hline Counties & Population $\left.\mathbf{( 1 0}^{\mathbf{4}}\right)$ & $\begin{array}{c}\text { Urbanization } \\
\text { Rate }\end{array}$ & $\begin{array}{c}\text { GDP } \\
\text { (Billion Yuan) }\end{array}$ & $\begin{array}{c}\text { Industry Structure (Primary Industry: } \\
\text { Secondary Industry: Tertiary Industry) }\end{array}$ \\
\hline Qilian & 4.70 & - & 0.52 & $24: 38: 38$ \\
Ganzhou & 51.60 & 37.00 & 7.67 & $25: 36: 40$ \\
Sunan & 3.64 & 30.80 & 0.94 & $21: 61: 18$ \\
Minle & 24.00 & 13.90 & 1.92 & $37: 33: 31$ \\
Linze & 14.70 & 16.00 & 2.18 & $41: 37: 25$ \\
Gaotai & 15.80 & 16.00 & 2.09 & $22: 42: 36$ \\
Shandan & 19.80 & 34.80 & 2.22 & $13: 54: 34$ \\
Suzhou & 40.64 & 43.50 & 6.20 & $30: 30: 40$ \\
Jinta & 14.70 & 23.80 & 2.40 & $1: 82: 17$ \\
Jiayuguan & 18.59 & 88.90 & 14.40 & $3: 61: 36$ \\
Ejina & 1.65 & 70.00 & 2.04 & \\
\hline
\end{tabular}

\subsection{Virtual Water Flows by Sector}

Figure 4 shows the virtual water flows at county level by sector in the Heihe River Basin (only amounts above 1.5 million $\mathrm{m}^{3}$ are shown). Of the 48 aggregated sectors, only 23 revealed both the import and export of virtual water. When all the counties were considered, the sectors with the highest virtual water import and export were the food manufacturing and tobacco processing industries in Jiayuguan County with 73.57 and 119.33 million $\mathrm{m}^{3}$, respectively, while the sector with the lowest virtual water import and export for all counties was the textile industry with 1.44 and 0.20 million $\mathrm{m}^{3}$, respectively. The sectors mainly responsible for virtual water import are the chemical industry, accommodation and catering, the food manufacturing and tobacco processing industries, and the metal smelting and rolling processing industries (Figure 4a). In contrast, the sectors that mainly export more virtual water than they import are maize production; the textile industry; transportation and warehousing; and textiles, clothing, shoes and hats, leather down and its products (Figure 4b). 


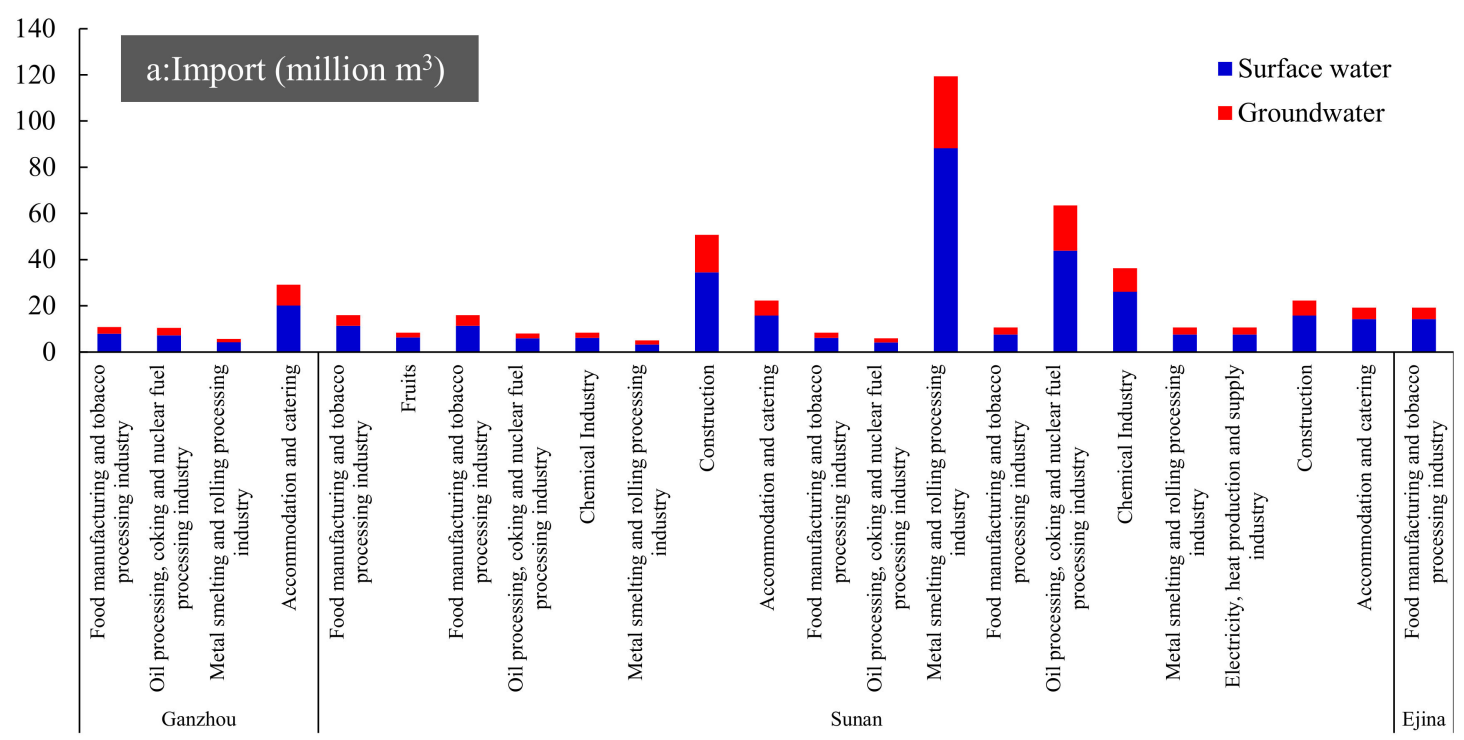

(a)

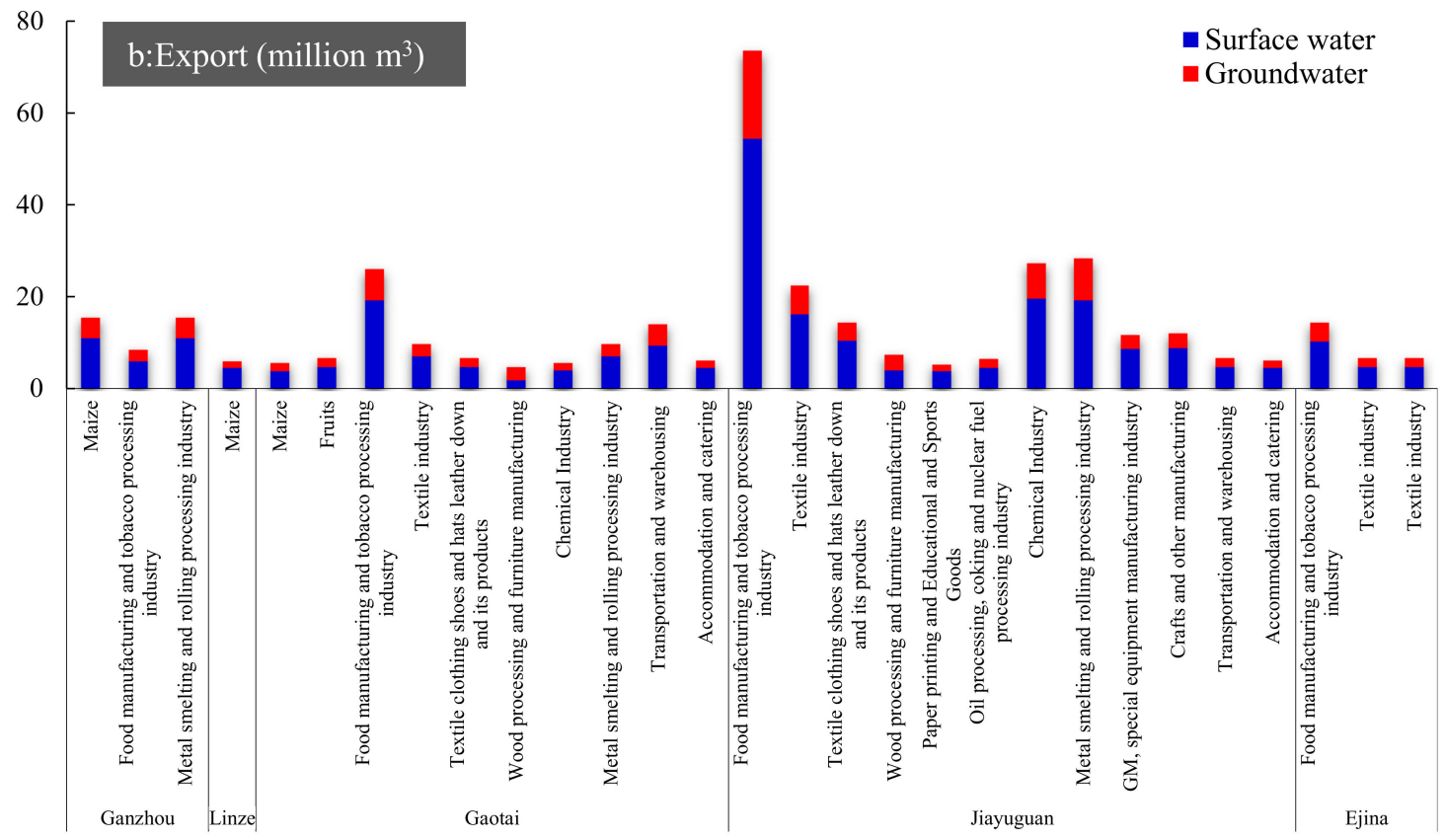

(b)

Figure 4. The inter-basin virtual water flows at the county level by sector in the Heihe River Basin. (a) virtual water import; (b) virtual water export.

In Ganzhou County, maize production dominated the largest contributor to the regional water stress, with a net virtual water export of 11.04 million $\mathrm{m}^{3}$. The studies on virtual water at the sector level inhibited that food and agriculture are crucial sectors affecting virtual water trade inter-regionally [24]. The service sector's influence on water stress varied from county to county. For instance, the virtual water export by leasing and business services in Suzhou and Jiayuguan Counties was around 16.00 million $\mathrm{m}^{3}$, while the virtual water import in Jiayuguan County ( 31.34 million $\mathrm{m}^{3}$ ) was almost triple that of Suzhou County (11.19 million $\mathrm{m}^{3}$ ). The leasing and business services sector in Jiayuguan County were presented to relieve the water shortage. Overall, the Heihe River Basin imported a small portion of virtual water (raw and processed food products) during the 10 years from 1997 to 2007 [25]. 
Most previous assessments of global water resources have focused on surface water. However, humans are overexploiting groundwater in many large aquifers that are critical to agriculture, especially in Asia and North America [26]. Figure 4 also provides virtual water flows by distinguishing between surface water and groundwater. Clearly, almost all the sectors experienced more virtual water flows from surface water than that from groundwater, with the ratio of surface water to groundwater virtual water ranging from 1.20 to 2.91 . An exception was the wood processing and furniture manufacturing sector in Suzhou County, where virtual water flows from groundwater exceeded those from surface water. This is possibly a result of Suzhou county having the highest utilizable groundwater resources (about 0.25 billion $\mathrm{m}^{3}$ ) among all the counties. However, it should be noted that more than $50 \%$ of groundwater has been seriously degraded as a result of the overuse of fertilizers and pesticides [27]. The discharge of high-concentrated pollution to surface flows from intensively pollution-generating production sectors (e.g., paper, chemicals, and textiles) has led to many major rivers in North China no longer being able to support any type of beneficial use because of their poor water quality. Water consumption in different sectors damaged water quality to some extent, which is vital for water-scarce regions. Policy about industry structure adjustment suggested that the sectors affecting water quality and consuming large amounts of water should be transferred to less-polluted and less-consumed sectors.

\subsection{Water Stress and Virtual Water Strategy}

Physical and virtual water use varied in different streams of the Heihe River Basin. The WSI formula was modified to accommodate virtual water flows. The results showed that physical water use, virtual water net imports, and renewable freshwater availability were the main causes of changes in water stress. Incorporating virtual water flows into water stress analysis permits a better understanding of what is causing water stress. Most of the 11 counties in the Heihe River Basin have experienced water stress, and had WSI values $>0.4$ in 2012 (Table 4). The areas with extremely high water stress included Sunan and Jiayuguan counties in the midstream area, and Qilian County in the upstream area. The WSI values for Sunan, Jiayuguan and Qilian counties were 3.02, 2.17 and 1.69, respectively. However, Ejina County in the downstream area did not experience water stress and had a WSI value of 0.09 . In fact, the physical water consumption and net virtual water import in the upstream and downstream areas were similar. This indicates that the large difference in water stress is driven by renewable freshwater availability (Table 4).

Table 4. Water stress index (WSI) at the county level in the Heihe River Basin.

\begin{tabular}{cccc}
\hline Streams & Counties & Renewable Freshwater Resources (Billion $\mathbf{~ m}^{\mathbf{3}}$ ) & WSI \\
\hline Upstream & Qilian & 0.02 & 1.69 \\
\hline & Ganzhou & 0.80 & 0.69 \\
& Sunan & 0.03 & 3.02 \\
& Minle & 0.40 & 0.36 \\
Midstream & Linze & 0.43 & 0.49 \\
& Gaotai & 0.34 & 0.63 \\
& Shandan & 0.13 & 0.70 \\
& Suzhou & 0.65 & 0.11 \\
& Jinta & 0.36 & -0.23 \\
& Jiayuguan & 0.11 & 2.17 \\
\hline Downstream & Ejina & 0.41 & 0.09 \\
\hline
\end{tabular}

National-level studies on virtual water have revealed that several economically advanced provinces, such as the cities of Beijing, Tianjin, Shandong, Shanghai, Zhejiang and Guangdong, have imported huge amounts of virtual water from outside to alleviate their water stresses $[15,28,29]$. This is especially applicable to the city of Beijing. Other researchers found that virtual water was exchanged and traded from arid regions to wet regions, and from north to south [24,30]. However, only about $5 \%$ 
of the total available water use can be attributed to net virtual water flows in north China [30]. Moreover, surface water has been polluted by highly polluting production sectors (e.g., paper, chemicals and textiles), and groundwater has been seriously degraded by agricultural activities. Thus, groundwater over-exploitation in the midstream areas of the Heihe River Basin should be highly valued.

From the viewpoint of water resource characteristics, water not only has natural properties, but also possesses socio-economic and ecological properties. Information about water scarcity only considers the water supply aspect, and neglects the water demand aspect [15,31]. That said, industrial structure's effect on water demand should be considered. Agricultural irrigation has a large water demand, while service industries need less water. Much research has been done on virtual water trade for relieving water stress [32-35]. However, the application of virtual water strategies to improve water use efficiency was challenged due to comprehensive capacities of economic level, social equity, infrastructural construction, and potential eco-environmental effect.

\section{Conclusions}

Multi-regional, input-output (MRIO) model at the county level for the Heihe River Basin was applied to analyze virtual water import and export in 2012. In total, the Heihe River Basin is a net virtual water exporter at a scale of 1.05 billion $\mathrm{m}^{3}$, accounting for one third of the total amount of water resources. The upstream and downstream areas of the basin had limited virtual water flows to and from the rest of the basin. However, the midstream exported $96.31 \%$ of virtual water to outside the basin, and imported $88.84 \%$ of virtual water from outside the basin. Ganzhou County accounted for the largest virtual water import and export ( 0.20 and 0.47 billion $\mathrm{m}^{3}$, respectively). The top three exporters of inter-basin virtual water flows were Ganzhou, Linze and Gaotai Counties, and the amount of water exported was $0.91,0.71$ and 0.66 million $\mathrm{m}^{3}$, respectively. Corn or wheat production in the agricultural sector accounts for the biggest proportion (almost 50\%) of total water consumption by sector. For most of the sectors, the virtual water content from surface water is greater than that from groundwater; the ratio of virtual surface water to virtual groundwater ranges from 1.20 to 2.91. The food manufacturing and tobacco processing industry had the highest amount of imported and exported virtual water (119.33 and 73.57 million $\mathrm{m}^{3}$, respectively). In contrast, the textile industry had the lowest amount of virtual water import and export (1.44 and 0.20 million $\mathrm{m}^{3}$, respectively).

Maize production was the largest contributor to regional water stress. Most counties in the Heihe River Basin experienced water stress, and extremely high water stresses occurred in the Sunan, Jiayuguan and Qilian Counties with WSI values of 3.02, 2.17 and 1.69, respectively. Further studies on the application of virtual water strategies in arid regions should take into consideration the comprehensive capacity of economic levels, social equity, infrastructural construction and potential eco-environmental effects.

Acknowledgments: This research was financially supported by the youth fund and major research plan of the National Natural Science Foundation of China (Grant Nos. 71704172; 91425303). The research fund for the new researcher of "Institute of Geographic Sciences and Natural Resources Research, Chinese Academy of Sciences" (Grant No. Y6V60224YZ) is also acknowledged.

Author Contributions: Yali Zhang designed the research topic and drafted the manuscript; Feng Wu contributed to the methodology of the study and edited the manuscript; Qing Zhou shared the efforts in data analysis and provided suggestions to revise the paper.

Conflicts of Interest: The authors declare that there are no conflicts of interest regarding the publication of this paper.

\section{References}

1. Vörösmarty, C.J.; McIntyre, P.B.; Gessner, M.O.; Dudgeon, D.; Prusevich, A.; Green, P.; Glidden, S.; Bunn, S.E.; Sullivan, C.A.; Liermann, C.R. Global threats to human water security and river biodiversity. Nature 2010, 467, 555-561. [CrossRef] [PubMed] 
2. Palmer, M.A.; Liu, J.G.; Matthews, J.H.; Mumba, M.; D'Odorico, P. Manage water in a green way. Science 2015, 349, 584-585. [CrossRef] [PubMed]

3. Allan, J.A. 'Virtual Water': A Long Term Solution for Water Short Middle Eastern Economies? School of Oriental and African Studies, University of London: London, UK, 1997.

4. Ansink, E. Refuting two claims about virtual water trade. Ecol. Econ. 2010, 69, 2027-2032. [CrossRef]

5. Antonelli, M.; Sartori, M. Unfolding the potential of the virtual water concept. What is still under debate? Environ. Sci. Policy 2015, 50, 240-251. [CrossRef]

6. Jia, S.; Long, Q.; Liu, W. The fallacious strategy of virtual water trade. Int. J. Water Resour. Dev. 2017, 33, 340-347. [CrossRef]

7. Dalin, C.; Konar, M.; Hanasaki, N.; Rinaldo, A.; Rodriguez-Iturbe, I. Evolution of the global virtual water trade network. Proc. Natl. Acad. Sci. USA 2012, 109, 5989-5994. [CrossRef] [PubMed]

8. Chen, G.; Li, J. Virtual water assessment for Macao, China: Highlighting the role of external trade. J. Clean. Prod. 2015, 93, 308-317. [CrossRef]

9. Hoekstra, A.Y.; Chapagain, A.K.; Oel, P.R. Advancing water footprint assessment research: Challenges in monitoring progress towards sustainable development goal 6. Water 2017, 9, 438. [CrossRef]

10. Suweis, S.; Konar, M.; Dalin, C.; Hanasaki, N.; Rinaldo, A.; Rodriguez-Iturbe, I. Structure and controls of the global virtual water trade network. Geophys. Res. Lett. 2011, 38. [CrossRef]

11. Ohlsson, L.; Turton, A.R. The turning of a screw: Social resource scarcity as a bottle-neck in adaptation to water scarcity. In Occasional Paper Series; School of Oriental and African Studies Water Study Group, University of London: London, UK, 1999.

12. Wichelns, D. Virtual water: A helpful perspective, but not a sufficient policy criterion. Water Resour. Manag. 2010, 24, 2203-2219. [CrossRef]

13. Hoekstra, A.Y. Human appropriation of natural capital: A comparison of ecological footprint and water footprint analysis. Ecol. Econ. 2009, 68, 1963-1974. [CrossRef]

14. Cheng, G.; Li, X.; Zhao, W.; Xu, Z.; Feng, Q.; Xiao, S.; Xiao, H. Integrated study of the water-ecosystem-economy in the Heihe River Basin. Natl. Sci. Rev. 2014, 1, 413-428. [CrossRef]

15. Dalin, C.; Qiu, H.; Hanasaki, N.; Mauzerall, D.L.; Rodrigueziturbe, I. Balancing water resource conservation and food security in China. Proc. Natl. Acad. Sci. USA 2015, 112, 4588-4593. [CrossRef] [PubMed]

16. White, D.J.; Feng, K.; Sun, L.; Hubacek, K. A hydro-economic MRIO analysis of the Haihe River Basin's water footprint and water stress. Ecol. Model. 2015, 318, 157-167. [CrossRef]

17. Mubako, S.; Lahiri, S.; Lant, C. Input-output analysis of virtual water transfers: Case study of California and Illinois. Ecol. Econ. 2013, 93, 230-238. [CrossRef]

18. Pfister, S.; Koehler, A.; Hellweg, S. Assessing the environmental impacts of freshwater consumption in LCA. Environ. Sci. Technol. 2009, 43, 4098-4104. [CrossRef] [PubMed]

19. Chen, W.; Wu, S.; Lei, Y.; Li, S. Virtual water export and import in china's foreign trade: A quantification using input-output tables of China from 2000 to 2012. Resour. Conserv. Recycl. 2017. Available online: http:/ / www.sciencedirect.com/science/article/pii/S0921344917300654 (accessed on 6 September 2017).

20. Bulsink, F.; Hoekstra, A.; Booij, M.J. The water footprint of Indonesian provinces related to the consumption of crop products. Hydrol. Earth Syst. Sci. 2010, 14, 119-128. [CrossRef]

21. Zhang, Z.; Yang, H.; Shi, M.; Zehnder, A.; Abbaspour, K. Analyses of impacts of China's international trade on its water resources and uses. Hydrol. Earth Syst. Sci. 2011, 15, 2871. [CrossRef]

22. Liu, J.; Wang, Y.; Yu, Z.; Cao, X.; Tian, L.; Sun, S.; Wu, P. A comprehensive analysis of blue water scarcity from the production, consumption, and water transfer perspectives. Ecol. Indic. 2017, 72, 870-880. [CrossRef]

23. Wang, P.; Li, Z.; Gao, W.; Yan, D.; Bai, J.; Li, K.; Wang, L. Glacier changes in the heihe river basin over the past 50 years in the context of climate change. Resour. Sci. 2011, 33, 399-407.

24. Zhang, C.; Anadon, L.D. A multi-regional input-output analysis of domestic virtual water trade and provincial water footprint in China. Ecol. Econ. 2014, 100, 159-172. [CrossRef]

25. Jin, C.; Huang, K.; Yu, Y.; Zhang, Y. Analysis of influencing factors of water footprint based on the stirpat model: Evidence from the beijing agricultural sector. Water 2016, 8, 513. [CrossRef]

26. Gleeson, T.; Wada, Y.; Bierkens, M.F.; van Beek, L.P. Water balance of global aquifers revealed by groundwater footprint. Nature 2012, 488, 197-200. [CrossRef] [PubMed] 
27. Dong, B.; Mao, Z.; Brown, L.; Chen, X.; Peng, L.; Wang, J. Irrigation ponds: Possibility and potentials for the treatment of drainage water from paddy fields in Zhanghe irrigation system. Sci. China Ser. E Technol. Sci. 2009, 52, 3320-3327. [CrossRef]

28. Zhang, Z.; Shi, M.; Yang, H. Understanding Beijing's water challenge: A decomposition analysis of changes in Beijing's water footprint between 1997 and 2007. Environ. Sci. Technol. 2012, 46, 12373-12380. [CrossRef] [PubMed]

29. Wang, Z.; Huang, K.; Yang, S.; Yu, Y. An input-output approach to evaluate the water footprint and virtual water trade of Beijing, China. J. Clean. Prod. 2013, 42, 172-179. [CrossRef]

30. Guan, D.; Hubacek, K. Assessment of regional trade and virtual water flows in China. Ecol. Econ. 2007, 61, 159-170. [CrossRef]

31. Deng, X.Z.; Zhang, F.; Wang, Z.; Li, X.; Zhang, T. An extended input output table compiled for analyzing water demand and consumption at county level in China. Sustainability 2014, 6, 3301-3320. [CrossRef]

32. Feng, K.; Siu, Y.L.; Guan, D.; Hubacek, K. Assessing regional virtual water flows and water footprints in the yellow river basin, china: A consumption based approach. Appl. Geogr. 2012, 32, 691-701. [CrossRef]

33. Hoekstra, A.Y.; Mekonnen, M.M.; Chapagain, A.K.; Mathews, R.E.; Richter, B.D. Global monthly water scarcity: Blue water footprints versus blue water availability. PLoS ONE 2012, 7, e32688. [CrossRef] [PubMed]

34. Deng, X.; Zhao, C. Identification of water scarcity and providing solutions for adapting to climate changes in the Heihe River Basin of China. Adv. Meteorol. 2015, 2015, 1-13. [CrossRef]

35. Fracasso, A.; Sartori, M.; Schiavo, S. Determinants of virtual water flows in the mediterranean. Sci. Total Environ. 2016, 543, 1054-1062. [CrossRef] [PubMed]

(C) 2017 by the authors. Licensee MDPI, Basel, Switzerland. This article is an open access article distributed under the terms and conditions of the Creative Commons Attribution (CC BY) license (http:/ / creativecommons.org/licenses/by/4.0/). 